\title{
Willingness to Pay for Watershed Improvement in Mekelle City Region: A Policy Implications of Payment for Ecosystem Services (PES schemes)
}

\author{
Shishay kiros weldegebriel ${ }^{1 *} \quad$ Kumelachew Yeshitela ${ }^{2}$ \\ 1.Ethiopian Civil Service University, Addis Ababa, Ethiopia \\ 2.Ethiopian Institute of Architecture, Building Construction and City Development, Addis Ababa University, \\ Addis Ababa, Ethiopia
}

\begin{abstract}
The purpose of this study was to model the willingness to pay for watershed ecosystem services improvement and analyze factors that affect households' support decisions. The city of Mekelle is dependent on multiple ecosystem services beyond the city administrative boundary. The data was obtained from a field data among 384 respondents and expert focus group discussion were used as data sources. The house hold survey was analyzed using econometric model and descriptive stastics by utilizing STATA MP v.14.The data revealed that as per the scenario presented the majority of the respondents 352 (91.7\%) were willing to support watershed ecosystem services improvement through regular financial fund while $32(8.3 \%)$ are not willing to support. The mean WTP is 65.18 Ethiopian birr monthly payment as additional to the current monthly fee of environmental services. Respondents' willingness to pay was influenced by bid amount, membership in environmental organization, long stay in the city, house ownership and awareness on the concept of watershed. Respondents were willing to pay because they wanted a sustainable ecosystem services supply for the present and future generations. A payment scheme is possible and it could provide a sustainable flow of fund, however, the willingness percentages still needed to be increased. Community education and public awareness is necessary to enhance knowledge and understand about the importance and values of watersheds. The findings from this study provide noteworthy evidences for further research and baseline information for local government in the development of more operative and all-inclusive approaches for improving watershed ecosystem services.
\end{abstract}

Keywords: Econometric model, Payment for ecosystem services, Watershed ecosystem Services, Willingness to Pay

DOI: $10.7176 / \mathrm{JESD} / 12-5-03$

Publication date:March $31^{\text {st }} 2021$

\section{Introduction}

Watersheds provide numerous ecosystem services (ESs) to downstream communities often with no cost to them. Non-optimal use of the natural resources leads to the degradation of the watersheds. One approach that could address this issue is payments for ecosystem services (Margaret Mejorada Calderon, 2012). Payment for ecosystem service(PES) institutions can be developed around specific ecosystem services or around the more general environmental outcomes from conservation (Max Nielsen-Pincus, 2017). Wunder defined PES as a voluntary transaction where a well-defined ecosystem service or a land use likely to secure that service is being bought by a minimum one ecosystem services buyer from a minimum one ecosystem services provider if and only if the ecosystem services provider secures ecosystem services provision(Danyang Feng, 2018).

Watershed services have been historically undervalued by virtue of many watersheds' treatment as a common or a public good. To overcome this tragedy of the commons payment for watershed services institutions may be designed to incentivize collective behaviour that coordinates the actions of public and private actors in a watershed (Max Nielsen-Pincus, 2017).Neoclassical economists used marginal utility gained by an individual from the last unit consumed to explain the market price of the given commodity. Further the neoclassical replaced classical notions of absolute scarcity with relative values as determined by the forces of demand and supply (Perman, Ma, McGilvray, \& Common, 2003).Economists place total economic value on the flow of natural resources. Total willingness to pay for environmental resources is the sum of use value, option value and non-use value (Tietenberg, 2003).

Environmental goods and services are not traded and their value cannot be determined in the market. This is a challenge to policy makers in cost- benefit analysis of projects which involve environmental benefits and costs. Therefore, economists require non-market valuation techniques to value environmental goods and services. Economists devised various valuation methods to attach economic values to non-marketed economic resources. Including indirect i.e. revealed preference method and direct expressed, stated preference methods. The indirect i.e revealed preference methods involves inferring the unobservable demand, and hence value of environmental goods and services, based on observable demand for related marketable goods and services. That is, economists try to infer the demand for environmental goods and services by using information on market transaction for related 
goods and services(Freeman, 1993).

Ecosystem services consumed in Mekelle city region such as water and other services are increasingly provided from the hinterlands. Many ecosystems are under pressure and are being degrade and destroyed. Several ecosystem services are in poor condition and declining. The current situation indicates the peri-urban ecosystems are increasingly at risk of degradation, loss of natural resource and market prices do not capture full ecosystem service value.

The problem impacts the ecosystem services and the wellbeing of society in the city region. Vulnerability extends to urban populations that depend on the ecosystem services provided by or flowing through peri-urban areas. Integrated watershed management is practiced in the upper catchment of Mekelle city region that benefit the city residents. Upstream watersheds can affect the household's water quality and quantity and other ecosystem services demand if sustainable funding is not put in place through awareness creation to city residents. Local farmers participation in watershed improvements is not adequate to sustain the provision of ecosystem services to city residents. Sustainable watershed management planning in the study area particularly in Mekelle city can be hampered due to financial capacities limited to undertake watershed conservation. Some of the contingent valuation method (CVM) studies done only on improved water supply services in developing countries in general and Ethiopia in particular. However, there are limited researches undertaken on WTP for improved watershed ecosystem service provision. In addition, to this PES and WTP focused only on single ecosystem services. Therefore, the objectives of this study were to: estimate the willingness to pay of Mekelle city residents for watershed ecosystem services improvements, analyze the determinant factors that affect households' willingness to pay and suggest possible solutions for sustainable watershed ecosystem services provision.

\section{Materials and Method}

\subsection{Study area}

The study area landscape (Figure 1) is located within Tigray region, northern part of Ethiopia found in west 39.362942, East 39.687048, North 13.680920 and south 13.342621 about $760.61 \mathrm{~km}$ north of Addis Ababa and the area covered in this investigation is 897.12 square kilometers ( 89,712 hectares).The study area is located within the Giba river catchment which is one of the biggest tributaries of the Tekeze river basin and has an area of 4019 $\mathrm{km}^{2}$ (Aredehey, Mezgebu, \& Girma, 2018).

The study area is characterized by varied topographic conditions. The elevation ranges from 1700 in the Geba river to 2685 Ellala and Gebat river catchment. The climate is predominantly semi-arid with irregular rainfall and frequent drought periods. The mean annual rainfall of the is estimated to be less than $532 \mathrm{~mm}$ (Veen, 2014).Climatically, the area has a semi-arid climate with little variation and it is knowns by its environmental vulnerability (Abreha, 2014). The agro-climatic zone of the study area is mild climatic condition. The Monthly mean minimum temperature is $15^{\circ} \mathrm{C}$ and maximum monthly temperature may go as high as $28^{\circ} \mathrm{C}$. The study area population is 556127 (TCSA, 2019). Similar to other arid and semiarid regions, most rivers and springs in the study area significantly decrease their discharge to unreliable levels (for domestic and small scale irrigation water supply) starting from the early or mid-months of the dry season and usually they become dry in the late months of the dry season(Girmay et al., 2015).

Figure 1: Location map of the study area major Watersheds and Mekelle's Sub-cities

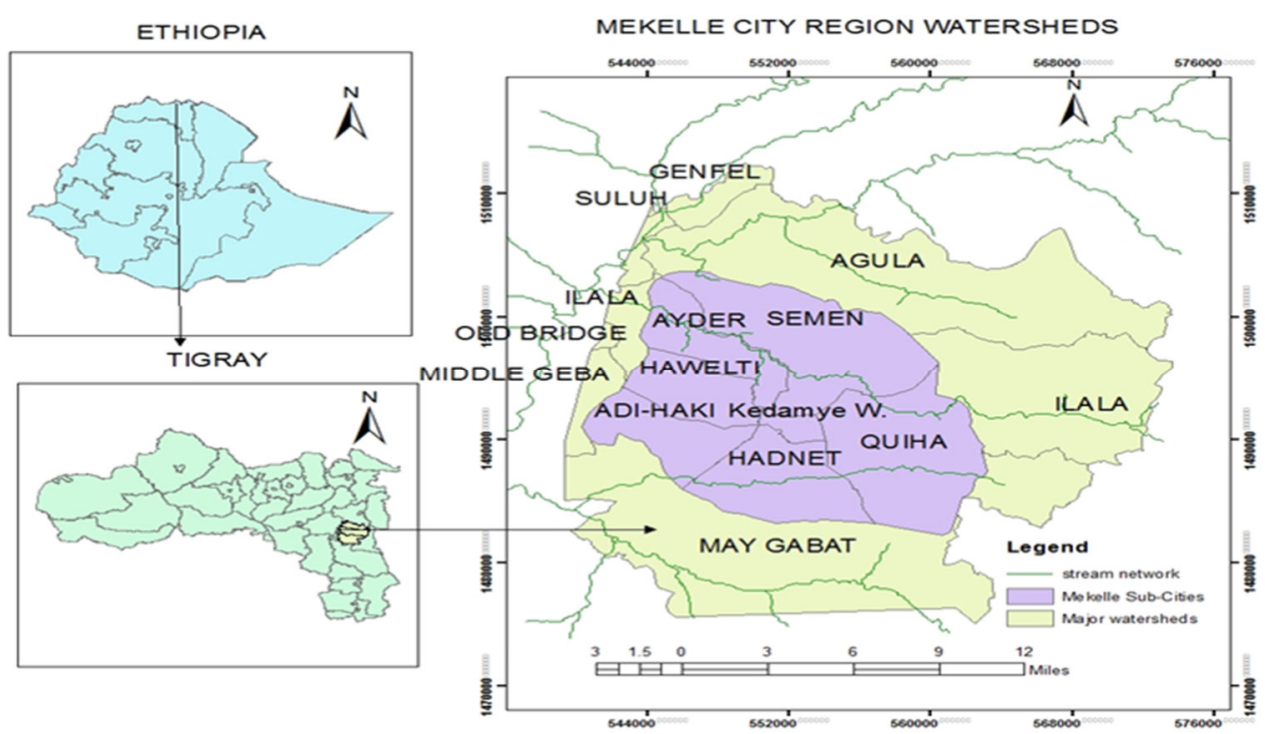

Source: Author,2020 


\subsection{Data sources}

In order to generate quantitative data from households close-ended questionnaire based on the objectives of the study was prepared. The contingent valuation method was a survey technique designed to elicit the willingness of a household to pay for a policy that will produce benefits for that household. After designing the draft questionnaire pre-testing was conducted by selecting a 42 random sample household from each Mekelle's sub cities which was done by four experienced interviewers and the author himself. The pre-test provided some information to make some modification in the design of the final survey based on the responses so as to make it understandable for respondents and to enable the interviewers to meet the objective of the study.

The study has applied double bounded dichotomous choice survey design to investigate empirically the willingness to pay towards improvement of watersheds ecosystem services. By asking each respondent a doublebounded dichotomous choice question which second question depends on the response to the first question and to persuade respondents to state their true value was applied. The WTP survey consist three main categories: public awareness about ecosystem services, present behavior and opinions on conservation of ecosystem services in Mekelle city region, future willingness to pay for conservation of upstream land for improvement of household water quality and other important ecosystem services for Mekelle city residents. The survey launched with focus group sessions and consultations with stakeholders to define the good to be valued. The field survey was successfully completed with a relatively small number of missed variables $(2.5 \%)$.

The elicitation scenario was shown to respondents during the survey followed up by WTP order of questions. The sequence of elicitation of values from respondents followed the use of land-use/cover conversion scenario between 1972 and 2019 as the basis for assigning monetary values. The six images that were presented to respondents indicating the historical trend of land use/land cover changes and the severity of environmental degradation in the past 47 years and with the hope the LULC changes would be halted with a hypothetical WTP. The respondents were asked whether or not he or she is willing to contribute a fund that will be used for the improved management of the watersheds. The focus group discussants suggested that the maximum amount that households of Mekelle city residents can be willing to pay was calculated by labour contribution of farmers for 40 days (20 days contribution) 700 Ethiopian birr per year divide to 12 months which is 60 birr.

\section{Willingness to pay Scenario Elicitations}

Six Images were presented to respondents indicating the trend of land use/land cover changes in Mekelle city region i.e Scenario A: current trend of LULC changes will continue and Scenario B: current trend of LULC changes would be halted with a hypothetical WTP.

\section{Sampling Techniques}

The study employed both probability and non-probability sampling techniques. For household survey, the scope of the population was considered to be all beneficiaries of the watershed ecosystem services for the city of Mekelle. The beneficiary list for the CVM survey consisted 423,174. city residents were required for sample extraction. For CVM survey multi-stage sampling was applied. First stage, all sub-cities were chosen in Mekelle city. Followed by random number of kebeles (smallest administrative unit). Then third stage units were house hold head was selected and 384 households were surveyed based on sample size using systematic random sampling. The study has used sample size determination formula developed by (Krejcie \& Morgan, 1970).Based on this 384 households were surveyed.

\subsection{Method of Data Analysis}

The household survey was analyzed using econometric models of probit, bi- variate probit and Tobit models. This study focused on the double-bounded dichotomous choice question format to elicit the WTP for the purpose of statistical efficiency and consistency.This double-bounded approach is shown to be asymptotically more efficient than the conventional single bounded approach(Hanemann, Loomis, \& Kanninen, 1991).

\section{The Probit Model}

This model used to analyze the responses to the close-ended dichotomous format, individuals were given the initial bid that has yes or no responses. The model is specified as follows:

$\mathrm{WTP} i=\beta \mathrm{O}+\beta 1 \mathrm{SEX}+\beta 2 \mathrm{EDUR} 1+\beta 3 \mathrm{EDUR} 2+\beta 4 \mathrm{EDUR} 3+\beta 5 \mathrm{EDUR} 4+\beta 6 \mathrm{EDUR} 5+\beta 7 \mathrm{EDUR} 6+\beta 8 \mathrm{FAMS}+\beta 9$

OCCR $+\beta 10$ AWRES $+\beta 11$ RCSAT $+\beta 12$ REYS $+\beta 13$ HOWNER $+\beta 14$ INCM $+\beta 15$ IB $+\beta 16$ EMEM $+\beta 17$ MAR+ $\beta 18 \mathrm{QUAN}+\beta 19 \mathrm{RLTY}+\beta 20 \mathrm{QLTY}+\beta 21 \mathrm{FEES}+\varepsilon i$

Where WTPi $=$ response to the 'bid' which is 1 if the response is 'Yes', 0 if the response is 'No', $\beta i$ is the regression parameter, $\varepsilon \mathrm{i}$ is the error term and the independent variables are defined in the variable description part. The regression parameters were estimated by maximum likelihood estimator (MLE) using STATA econometric software. To estimating the WTP model based on a CVM the mean was needed. The measures of central tendency i.e. the mean and the median measures are the most widely used measures of welfare change. In this study the mean was employed to calculate the total benefit that will derive from watershed ecosystem services improvement and this was calculated using the probit for the single bounded dichotomous questions.

Mean WTP $=\mu=-\sigma / \beta$ Where $\sigma=$ is the constant term, $\beta$ is the coefficient of the bid posed to the respondent and $\mu$ 
=population mean

\section{Bi-variate probit model}

In the bi-variate probit model of double-bounded dichotomous choice format, city residents' households were asked two respective questions that has Yes or No responses where the second question involves another bid depending on the first answer. There were four possible responses of single house hold ' $\mathrm{j}$ 'from his/her responses of 'Yes' or 'No'.

YES-YES, if his/her response is 'Yes' for both the first and the second bid ( $\beta 1$ and $\beta 2), W T P j>\beta 2$; YES-NO, if the individual's response is 'Yes' for the first bid $(\beta 1)$ and 'No' for the second bid $(\beta 2),(\beta 1 \leq \mathrm{WTPj}<\beta 2)$; NO-No, if his/her response is 'No' for the first bid $(\beta 1)$ and 'No' for the second bid ( $\beta 2)$.NO-YES, if the individual response is 'No' for the first bid $(\beta 1)$ and 'Yes' for the second bid $(\beta 2)$. Therefore, the probability of observing one of the possible two bid responses can be given as: $\operatorname{Pr}($ Yes, Yes $)=\operatorname{Pr}(W T P j 1>\beta 1, W T P j 2>\beta 2) ; \operatorname{Pr}(Y e s, \operatorname{No})=\operatorname{Pr}$ $(\mathrm{WTPj} 1>\beta 1, \mathrm{WTPj} 2<\beta 2) ; \operatorname{Pr}(\mathrm{No}, \mathrm{Yes})=\operatorname{Pr}(\mathrm{WTPj} 1<\beta 1, \mathrm{WTPj}>\beta 2)$ and $\operatorname{Pr}(\mathrm{No}, \mathrm{No})=\operatorname{Pr}(\mathrm{WTPj} 1<\beta 1$, WTPj2 $<\beta 2$ )

\section{The Tobit models (censored regression model)}

In this study the respondents' WTP survey responses from the open-ended questionnaire was estimated using Tobit model. Some respondents had low maximum willingness to pay and here Tobit model is used.The model for the censored data is:

MWTP $=\alpha_{0}+\alpha_{1}$ SEX $+\alpha_{2}$ EDUR1 $+\alpha_{3}$ EDUR2 $+\alpha_{4}$ EDUR3 $+\alpha_{5}$ EDUR4 $+\alpha_{6}$ EDUR5 $+\alpha_{7}$ EDUR6 $+\alpha_{8}$ FAMS + $\alpha_{9} \mathrm{OCCR}+\alpha_{10}$ AWRES $+\alpha_{11}$ RCSAT $+\alpha_{12}$ REYS $+\alpha_{13}$ HOWNER $+\alpha_{14}$ INCM $+\alpha_{15}$ IB $+\alpha_{16}$ EMEM $+\alpha_{17}$ MAR $+\alpha$ $18 \mathrm{QUAN}+\alpha$ 19RLTY $+\alpha 20 \mathrm{RLTY}+\alpha 21 \mathrm{FEES}+\varepsilon \mathrm{i}$

Where MWTP is the maximum willingness to pay in birr for household $i$ and is observed if it is greater than zero but not observed when it is less than or equal to zero. $\sigma 0, \sigma 1$ $\sigma 17$ are regression parameters and $\varepsilon i$ is the error term. For the open-ended CV survey responses, maximum WTP reported by the respondents was simply averaged to produce an estimate of mean WTP.The payment for ecosystem service in this study (Figure 2) is used to describe arrangements in which the beneficiaries of ecosystem services of Mekelle city residents provide payment to the stewards or providers of ESs of the upstream watershed ESs providers communities who are practicing environmentally friendly practices.

Figure 2: Diagrammatical representation of upstream and downstream in the study area

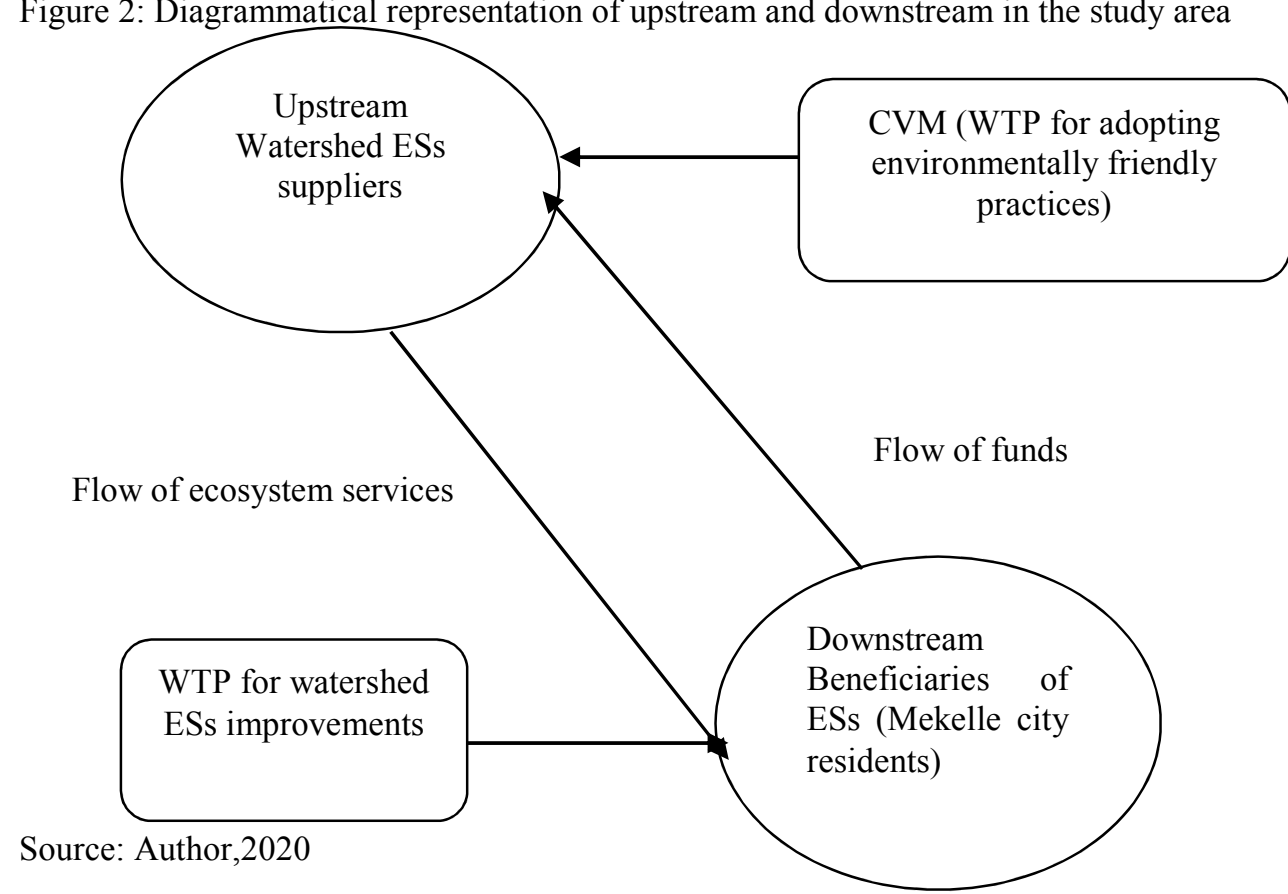

\section{Results}

\subsection{Households willingness to pay for improved watershed ecosystem Services}

As per the scenario presented in the survey the majority of the respondents $352(91.7 \%)$ replied they are willing to support watershed ecosystem services improvement through WTP regular financial fund, while 32(8.3\%) are not willing to support. Numerous reasons are motivating a growth in demand and willingness to pay for ecosystem services for Mekelle city residents. The public awareness on the depletion of water ecosystem services and others is growing. From the surveyed respondents, the reasons for their WTP for watershed improvements are $238(67.61 \%)$ to get clean water, $135(38 \%)$ for formation of a learning community at sustained basis ,120(34\%) for watersheds to continue producing other ecosystem services such as biodiversity conservation, recreation, 
food, $120(34 \%)$ for future generations to use,118(33.5\%) for income and employment generation activities and $105(29.83 \%)$ believe that the city administration will do a good job in administering the fund that will be collected.

From the 32 respondents who are not willing to contribute any amount to the fund they indicated reasons for not willing to contribute to the fund/support the for watershed improvements was $32(100 \%)$ cannot afford to pay any additional amount to what they are currently paying and are paying at present too high,22(68.75\%)replied that it should be the government to finance the watershed management activities and consider as it is not their responsibility to pay for watershed conservation,10(31.25\%) believe the current tariff could improve the water shade management,9(28.12\%)they not believe that improved watershed management will result in more reliable ecosystem service provision, $10(31.25 \%)$ respondents they not want to pay for watershed conservation outside Mekelle city,8(25)they did not trust the institution who will manage the funds for this conservation work,5(15.63) are satisfied with the existing watershed management,11(34.3\%)insisted that only the rich households should pay and $17(53.1 \%)$ Poor people will be affected by the scheme.

From the total of 352 respondents who are willing to support watershed ecosystem services improvement 287 $(81.53 \% \%)$ have said 'Yes' to pay an average initial bid amount of 60 ETB and $65(18.47 \%)$ have refused to pay this initial bid amount. The data also revealed that, from the total of 287 respondents who said 'Yes' to pay an initial bid amount of 60 ETB 131(45.64\%) accepted to pay higher bid price of 120 ETB per month and the majority $156(54.36 \%)$ refused to pay this higher bid amount. From the 156 who refused to pay 120 ETB 99(63.46\%) respondents are willing to pay 90 ETB whereas 57(36.54) refused to accept it.This data shows 156 respondents persisted and are willing to pay 60 ETB,32 respondents accepted to pay higher bid amount of 120 ETB and 42 respondents are willing to pay $90 \mathrm{ETB}$. The open-ended dichotomous choice result from the 57 respondents show the maximum amount of money that they are willing to pay on average is $71.75 \mathrm{ETB}$ which ranges from a minimum of 65 ETB to a maximum of 85 ETB. From 65 respondents who have refused to pay this initial bid amount of 60 ETB the majority 50(76.92) respondents are willing to pay $30 \mathrm{ETB}$, whereas the rest $15(23.08 \%)$ are not again willing to pay. But the 15 respondents finally revealed their maximum WTP is on average 19.33 which ranges from a minimum of 10 ETB to a maximum of 25 ETB

Table 1: Mean Willingness to Pay per month of overall responses

\begin{tabular}{|l|l|l|l|l|l|l|}
\hline & $\begin{array}{c}\text { Willingness to } \\
\text { pay monthly } \\
\text { payment of 60 } \\
\text { ETB }\end{array}$ & $\begin{array}{l}\text { willingness of } \\
\text { households to } \\
\text { pay 120 ETB } \\
\text { per month }\end{array}$ & $\begin{array}{l}\text { Willingness } \\
\text { pay 90 ETB }\end{array}$ & $\begin{array}{l}\text { to No 90 ETB } \\
\text { the maximum } \\
\text { willing to pay }\end{array}$ & $\begin{array}{c}\text { Willingness to } \\
\text { pay 30 ETB } \\
\text { per month }\end{array}$ & $\begin{array}{c}\text { If No 30 ETB } \\
\text { the maximum } \\
\text { willingness }\end{array}$ \\
\hline Mean & 60.0000 & 120.0000 & 90.0000 & 71.7544 & 30.0000 & 19.3333 \\
\hline Median & 60.0000 & 120.0000 & 90.0000 & 70.0000 & 30.0000 & 20.0000 \\
\hline Std. Deviation & .00000 & .00000 & .00000 & 6.01273 & .00000 & 3.19970 \\
\hline Range & .00 & .00 & .00 & 20.00 & .00 & 15.00 \\
\hline Minimum & 60.00 & 120.00 & 90.00 & 65.00 & 30.00 & 10.00 \\
\hline Maximum & 60.00 & 120.00 & 90.00 & 85.00 & 30.00 & 25.00 \\
\hline
\end{tabular}

The mean WTP (Table 1) is 65.18 ETB monthly payment as additional to the current monthly fee of environmental services (utility fees, sanitation).

The dependent variable is the WTP of households to support watershed ecosystem services (Table 1). The variable is Dummy variable, 1 if willing to support watershed ecosystem services improvement, 0 otherwise. In this dichotomous CVM study, the response of households for the hypothetical scenario is the key research questions. Given the existing ecosystem services problems in Mekelle city, it is obvious that the dependent variable WTP will generate demand. This study assumed that the city residents desire to maximize its expected utility. Another issue is whether the WTP by watershed service downstream users provide sufficient resources to compensate upstream watershed ecosystem service providers. Thus, the above twenty-one potential variables, which are assumed to influence households' WTP and were selected based on the findings of past studies and researcher's knowledge about the study area 
Table 2: Summary statistics of variables

\begin{tabular}{|c|c|c|c|c|c|}
\hline $\begin{array}{l}\text { Variable } \\
\text { name }\end{array}$ & Description & Mean & $\begin{array}{l}\text { Standard } \\
\text { deviation }\end{array}$ & Minimum & Maximum \\
\hline \multicolumn{6}{|c|}{ 1.Dependent variable } \\
\hline $\begin{array}{l}\text { Willingness } \\
\text { to support }\end{array}$ & $\begin{array}{l}\text { Dummy variable, } 1 \text { if willing to support for } \\
\text { watershed improvement, } 0 \text { otherwise }\end{array}$ & 0.92 & 0.277 & 0 & 1 \\
\hline \multicolumn{6}{|c|}{ 2.Independent variables } \\
\hline SEX & $\begin{array}{l}\text { Sex, Dummy variable with } 1 \text { for male and } 0 \\
\text { otherwise. }\end{array}$ & 0.61 & 0.488 & 0 & 1 \\
\hline EDUR1 & $\begin{array}{l}\text { Educational level, dummy variable } 1 \text { is non- } \\
\text { literate, } 0 \text { otherwise, }\end{array}$ & 0.23 & 0.419 & 0 & 1 \\
\hline EDUR2 & $\begin{array}{l}\text { Educational level, read and write } 1 \text { if } \\
\text { respondents can read and write, } 0 \text { otherwise }\end{array}$ & 0.0651 & 0.24703 & 0 & 1 \\
\hline EDUR3 & $\begin{array}{l}\text { Educational level, } 1 \text { is primary (from grade1- } \\
6 \text { ), } 0 \text { otherwise, }\end{array}$ & 0.1354 & 0.34261 & 0 & 1 \\
\hline EDUR4 & $\begin{array}{l}\text { Educational level, } 1 \text { for junior secondary } 0 \\
\text { other wise, }\end{array}$ & 0.1510 & 0.35856 & 0 & 1 \\
\hline EDUR5 & $\begin{array}{l}\text { Educational level, } 1 \text { if the respondents is } \\
\text { secondary (from Grade 9-12) and } 0 \\
\text { otherwise }\end{array}$ & 0.2031 & 0.40285 & 0 & 1 \\
\hline EDUR6 & $\begin{array}{l}\text { Educational level, } 1 \text { if the educational level } \\
\text { of the respondents is tertiary and } 0 \text { otherwise. }\end{array}$ & 0.2161 & 0.41215 & 0 & 1 \\
\hline FAMS & Family size of the respondent in number. & 3.30 & 1.81 & 1 & 8 \\
\hline OCCR & $\begin{array}{l}\text { Occupation, dummy variable taking the value } \\
1 \text { if the respondent has regular earnings and } 0 \\
\text { otherwise }\end{array}$ & 0.72 & 0.449 & 0 & 1 \\
\hline AWRES & $\begin{array}{l}\text { Awareness of respondents, } 1 \text { if the respondent } \\
\text { is aware and } 0 \text { otherwise }\end{array}$ & 0.29 & 0.456 & 0 & 1 \\
\hline RCSAT & $\begin{array}{l}\text { Respondents current satisfaction with the } \\
\text { existing watershed ecosystem service, } \\
\text { dummy variable which is } 1 \text { if the household is } \\
\text { not satisfied; } 0 \text { otherwise. }\end{array}$ & 0.83 & 0.373 & 0 & 1 \\
\hline REYS & Respondents years of stay in the city & 21.22 & 11.89 & 1 & 50 \\
\hline HOWNER & $\begin{array}{l}\text { House ownership, dummy variable taking the } \\
\text { value } 1 \text { if the respondent is house owner and } \\
0 \text { otherwise }\end{array}$ & 0.45 & 0.498 & 0 & 1 \\
\hline INCM & Total monthly income of the household & 3839.5 & 1992.3 & 300 & 15000 \\
\hline IB & $\begin{array}{l}\text { Initial bid price offered to the surveyed } \\
\text { respondents }\end{array}$ & 0.7474 & 0.43507 & 0 & 1 \\
\hline EMEM & $\begin{array}{l}\text { Membership in environmental group, dummy } \\
\text { variable taking the value } 1 \text { if the respondent is } \\
\text { member in environmental organization and } 0 \\
\text { otherwise. }\end{array}$ & 0.06 & 0.242 & 0 & 1 \\
\hline MAR & $\begin{array}{l}\text { Marital status, dummy variable taking the } \\
\text { value } 1 \text { if the respondent is married and } 0 \\
\text { otherwise. }\end{array}$ & 0.63 & 0.483 & 0 & 1 \\
\hline QUAN & Quantity of water & 2.58 & 0.581 & 1 & 3 \\
\hline RLTY & $\begin{array}{l}\text { Reliability of the existing source of water, a } \\
\text { dummy variable taking } 1 \text { if the existing } \\
\text { source is not reliable; } 0 \text { otherwise. }\end{array}$ & 0.72 & 0.449 & 0 & 1 \\
\hline QLTY & $\begin{array}{l}\text { Quality of water being used, dummy variable } \\
\text { taking } 1 \text { if the existing source of water is not } \\
\text { safe to drink; } 0 \text { otherwise. }\end{array}$ & 0.68 & 0.490 & 0 & 3 \\
\hline FEES & $\begin{array}{l}\text { Water utilities and environmental fees } \\
\text { judgement, dummy variable taking } 1 \text { if the } \\
\text { house pays currently pay high; } 0 \text { otherwise. }\end{array}$ & 0.1953 & 0.39696 & 0 & 1 \\
\hline
\end{tabular}




\subsection{Econometric Model Analysis}

This study assumed a single household to maximize the expected utility gain from participating in watershed ecosystem services improvement. Before proceeding into regression model analysis, the authors checked multicollinearity and undertake heteroscedastic test and those were not a serious problem.

\section{Probit Model Results}

The coefficients of the Probit model give the significance and the direction of the effects of each independent variable on WTP. The Probit estimation results were obtained using STATA/MP 14.0. The marginal effects show the probability that respondents accept or reject the offered bid due to a unit change in continuous explanatory variables and a change of dummy variables from 0 to 1 , for the discrete variables.

Table 3: Probit Regression Model

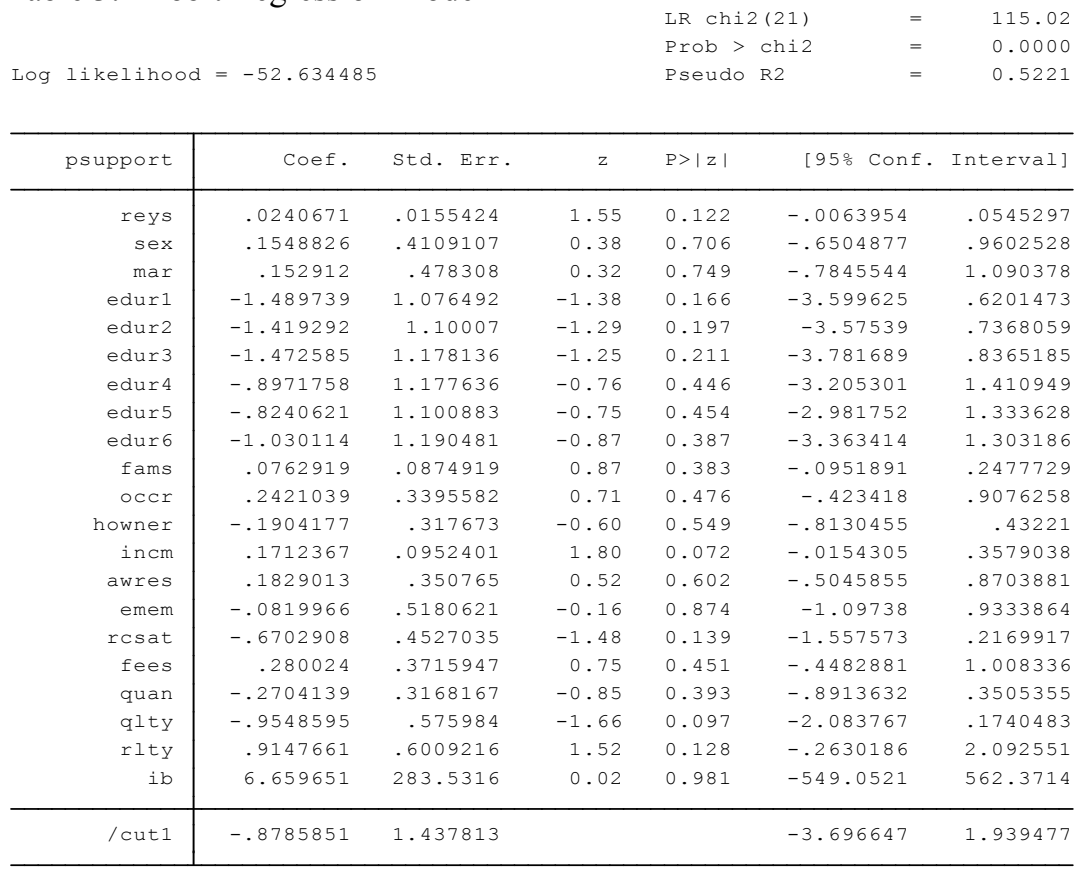

Note: 287 observations completely determined.

In the above table 3, the coefficients, their standard errors, the z-statistic, associated p-values, and the $95 \%$ confidence interval of the coefficients are indicated. The probit regression coefficients give the change in the $\mathrm{z}-$ score or probit index for a one-unit change in the predictor. The likelihood ratio chi-square of 115.03 with a $\mathrm{p}$ value of 0.000 tells us that the model as a whole is statistically significant. The Pseudo $\mathrm{R}^{2}$ is used here to measure the predictors efficiencies for goodness-of-fit measure. Pseudo R2 is a measure of how well variables of the model explain some phenomenon.

The number of years of stay in Mekelle city has positive and statistically significant effect (at the $1 \%$ level) on the probability of accepting the initial bid 60 ETB. In particular, the results suggest that when the household's years of stay in the city is increased by one year, the probability of saying 'Yes' for any initial bid offered to them. This is perhaps because households who stayed for long years are more aware about the severity of the water supply problem and other ecosystem services types and thus are willing to pay more for improved watershed ecosystem services.

The variable sex of the respondent has a positive sign of coefficient suggesting that male respondents are willing to pay more than female. The result is statistically significant and hence the variable can be considered statistically important. The marital status variable has positive sign of coefficient suggesting indicating married people are more willing to pay. This is due to the fact that married people are likely to be more responsible to sustain the watershed ecosystem services and hence are more likely to be willing to pay more. The results from EDUR1 up to EDUR6 the sign of coefficients ae negative. This suggest that WTP is not related with education.

The family size result showed that the variable has a positive sign coefficient which is statistically significant. There is positive relationship between willingness to pay and higher family size of the respondent. The higher family size showed in this study higher demand for ecosystem services particularly water supply, recreational activities etc. The sign of coefficient for occupation of respondents is positive and statistically significant. The sampled respondent who have regular earnings and who receive salary or paid monthly or weekly and is employed in formal sector such as government organization, private organization, NGOs, self-employed, work in religious institution are more willing than the unemployed, daily laborer, retired and house wives. The result suggests, regular income earners respondents are more willingness for improved watershed ecosystem service than the 
irregularly income earners households such as unemployed, daily laborers, house wives.

Despite, the fact ownership of a house, which is a proxy for wealth, in this study it has a negative sign coefficient which is stastically insignificant. The correlation coefficient for income of the household is positive, suggests that an increase in the income of the household increases the probability of accepting the initial bid offered to respondents. The correlation coefficient for awareness show that positive sign and suggests respondents who are aware of dependence that urban populations have on local and distant ecosystem services are more willing to pay for improved watershed ecosystem services. Membership in environmental group has negative sign of coefficient. Respondents current satisfaction with the existing watershed ecosystem service has negative sign of coefficient. Water utilities and environmental fees has positive sign of coefficient suggests that despite the high fees households are willing to pay for improved watershed ecosystem services.

The quantity and quality of water used by households has a negative sign coefficient. The variable representing reliability of the existing water source has a positive sign. This suggests that if households get a more reliable source of water from the watersheds, they are more likely to pay. The Initial bid offered to the respondents has a positive effect on the probability of accepting the bid and is significant. This suggests that increase in the initial bid will increases the likelihood that respondents are willing for a second bid to pay. Hence, the major factors that affect the initial bid amount are respondents' years of stay in the city, sex, marital status, family size, occupation, income, awareness, water utilities and environmental fees, reliability and initial bid.

\section{Bivariate-probit model}

The bivariate-Probit model (Table 4) used to examine whether the double-bounded value elicitation format increases statistical efficiency or not. To investigate the application of double bounded dichotomous choice format stastical instead of only employing single-bounded dichotomous format the bi-variate probit model was employed during the survey where the respondents were asked successive questions of the second bid amount closed ended question after the response of initial bid amount. For the respondent who accepts the initial bid amount of $60 \mathrm{ETB}$, second bid which is twice the initial bid was asked. For respondent who rejected the initial bid amount offered, half of the initial bid i.e 30 ETB was offered. Ten explanatory variables were significant in the Probit regression model. For the double bounded the initial and second bids were included.

Table 4: Bivariate probit regression

. biprobit ib secnbid

Fitting comparison equation 1

Iteration 0: log likelihood $=-217.02838$

Iteration 1: $\quad \log$ likelihood $=-217.02838$

Fitting comparison equation 2

Iteration 0: log likelihood $=-245.10874$

Iteration 1: $\quad \log$ likelihood $=-245.10874$

Comparison: $\quad$ log likelihood $=-462.13712$

Eitting full model:

Iteration 0: $\quad \log$ likelihood $=-462.13712$

Iteration 1: $\quad$ og likelihood $=-433.5498$

Iteration 2: $\quad$ log likelihood $=-432.99974$

Iteration 3: $\log$ likelihood $=-432.9988$

Iteration 4: $\quad \log$ likelihood $=-432.9988$

Log likelihood $=-432.9988$

\begin{tabular}{|c|c|c|c|c|c|c|}
\hline & Coef. & Std. Err. & z & $\mathrm{P}>|z|$ & [95\% Conf. & Interval] \\
\hline \multicolumn{7}{|l|}{$i b$} \\
\hline _cons & .6663173 & .0693951 & 9.60 & 0.000 & .5303054 & .8023291 \\
\hline \multicolumn{7}{|l|}{ secnbid } \\
\hline _cons & -.4235761 & .0660873 & -6.41 & 0.000 & -.5531048 & -.2940474 \\
\hline /athrho & .8370718 & .1239239 & 6.75 & 0.000 & .5941855 & 1.079958 \\
\hline rho & .684255 & .0659021 & & & .5328992 & .7931836 \\
\hline
\end{tabular}


From the above results the 'rho' that is the coefficient of correlation of error terms of the double bounded dichotomous choice model is positive which shows that the first and the second bid responses are positively correlated. From the test statistics, the initial bid offered to the household has positive sign indicating that when the bid offered increases the probability of accepting it also increases. The coefficient of the second bid offered is negative indicating when the bid offered increases the probability of accepting it also decreases. The output in the above table shows several iteration logs. The first iteration log corresponds to running the univariate probit model for the first equation, and the second log corresponds to running the univariate probit for the second model. If $\rho=$ 0 , the sum of the log likelihoods from these two models will equal the log likelihood of the bivariate probit model; this sum is printed in the iteration log as the comparison log likelihood. The final iteration log is for fitting the full bivariate probit model. A likelihood-ratio test of the log likelihood for this model and the comparison log likelihood is presented at the end of the output.

\section{Single-Bounded and Double-Bounded dichotomous choice Models Estimates}

The single-bounded format was estimated using the first bid by employing the Probit model. The double bounded model was estimated using the first and second bids offered to the respondents. The statistical efficiency of these two dichotomous choice question formats is presented below.

Table 5: Probit and Bi-Variate Probit model estimates

\begin{tabular}{|l|l|l|l|l|l|}
\hline Probit Model & \multicolumn{4}{l|}{ Bi-Probit Model } \\
\hline Coef. & Std. Err. & Z & Coef. & Std. Err. & Z \\
\hline .6663173 & .0693951 & 9.60 & .0030692 & .0025723 & 1.19 \\
\hline
\end{tabular}

The above table 5 indicates that the use of both single-bounded format and double-bounded increase statistical efficiency.

\section{Tobit model Analysis (censored regression model)}

Tobit model were used analyze the factors that influence the maximum amount of money that households are willing to pay. This is applied here to estimate the relationships between the independent variables when there is either left- or right-censoring in the dependent variable of willingness to pay (censoring from below WTP in the closed ended format). In the case of censoring from below the WTP threshold prepared are values those that fall at or below the maximum WTP threshold. The endogenous (dependent variable) variable. In the Tobit statistical model that's changed or determined by its relationship with other independent variables within the model is willingness to pay for the public support for watershed improvement.

Table 6: Maximum Likelihood Estimates of the Tobit model

$\begin{array}{llll} & \text { LR chi2(21) } & = & 134.51 \\ \text { Log likelihood }=-63.216922 & \text { Prob }>\text { chi2 } & = & 0.0000 \\ & \text { Pseudo R2 } & = & 0.5155\end{array}$

\begin{tabular}{|c|c|c|c|c|c|c|}
\hline psupport & Coef. & std. Err. & t & $P>|t|$ & [95\% Conf. & Interval] \\
\hline reys & .0010295 & .0012031 & 0.86 & 0.393 & -.0013363 & .0033954 \\
\hline sex & -.0015317 & .0312592 & -0.05 & 0.961 & -.0630036 & .0599402 \\
\hline $\operatorname{mar}$ & .0103326 & .0327234 & 0.32 & 0.752 & -.0540187 & .0746839 \\
\hline edur 1 & -.0929935 & .0904067 & -1.03 & 0.304 & -.2707801 & .0847931 \\
\hline edur2 & -.1197253 & .0932078 & -1.28 & 0.200 & -.3030204 & .0635698 \\
\hline edur 3 & -.0983325 & .0943629 & -1.04 & 0.298 & -.2838991 & .0872342 \\
\hline edur 4 & -.0619515 & .0926163 & -0.67 & 0.504 & -.2440834 & .1201805 \\
\hline edur 5 & -.0442114 & .0903647 & -0.49 & 0.625 & -.2219156 & .1334927 \\
\hline edur 6 & -.0590087 & .0928426 & -0.64 & 0.525 & -.2415856 & .1235682 \\
\hline fams & .0092911 & .0077882 & 1.19 & 0.234 & -.0060245 & .0246067 \\
\hline occr & -.0059766 & .0301168 & -0.20 & 0.843 & -.0652019 & .0532487 \\
\hline howner & -.0124352 & .026894 & -0.46 & 0.644 & -.0653229 & .0404524 \\
\hline incm & .0130664 & .008272 & 1.58 & 0.115 & -.0032007 & .0293335 \\
\hline awres & .0204855 & .0295613 & 0.69 & 0.489 & -.0376473 & .0786184 \\
\hline emem & .0283419 & .0549047 & 0.52 & 0.606 & -.0796292 & .1363131 \\
\hline rcsat & -.0481192 & .0358126 & -1.34 & 0.180 & -.1185454 & .0223071 \\
\hline fees & .0300607 & .0329694 & 0.91 & 0.362 & -.0347743 & .0948957 \\
\hline quan & -.028645 & .0334772 & -0.86 & 0.393 & -.0944786 & .0371887 \\
\hline rlty & .0487823 & .0441197 & 1.11 & 0.270 & -.0379799 & .1355446 \\
\hline qlty & -.0476869 & .038262 & -1.25 & 0.213 & -.1229299 & .0275562 \\
\hline$i b$ & .3611162 & .0311784 & 11.58 & 0.000 & .2998032 & .4224293 \\
\hline${ }_{-}$cons & .6909308 & .1319848 & 5.23 & 0.000 & .4313799 & .9504816 \\
\hline /sigma & .2518344 & .0098217 & & & .2325197 & .271149 \\
\hline
\end{tabular}

32 left-censored observations at psupport $<=0$

352 uncensored observations

0 right-censored observations

The likelihood ratio chi-square of 134.51 with a p-value of 0.0001 (Table 6 ) indicate that the model as a whole fit significantly better than an empty model i.e., a model with no predictors. The ancillary statistic /sigma is 
analogous to the square root of the residual variance in OLS regression. The value of 0.2518344 can be compared to the standard deviation. The output also contains an estimate of the standard error of /sigma as well as the $95 \%$ confidence interval. Finally, the output provides a summary of the number of left-censored, uncensored and rightcensored values. The Tobit regression result indicates the respondent's years of stay in the city and marital status is positively affected respondent's maximum willingness to pay. The households who stayed for a long period of time in the city are willing to pay a higher amount than those who lived for a shorter period perhaps because they were more aware about the severity of the water supply problem and other ecosystem services. The influence of sex in this study is negative. This show sex did not affect respondent's maximum willingness to pay. All the six educational dummy variables are affecting negatively the households' maximum willingness to pay.

Respondent's family size affected positively to maximum of respondents. But occupation and home ownership negatively affected to respondents MWTP. On the other hand, income, awareness and environmental members have positively affected to MWTP.The result for income is consistent with a priori expectation as it has a positive influence on the amount of money that households are willing to pay. Regarding respondent's current satisfaction with the existing watershed ecosystem service has negative sign of coefficient indicating it negatively affect MWTP.The water utilities and environmental fees have positive sign of coefficient. However, the quantity variable has negative sign of coefficient. Despite this, quality of water being used by households is negatively affecting the maximum amount that households are willing to pay. The dummy variable reliability of the existing source has also positive sign and this suggests that households for whom the existing source is not reliable are willing to pay. The result for the initial bid shows that it has a positive sign of coefficient. This initial bid is included in the estimation to test whether it creates a starting point bias on the responses of households' maximum amount of money that they are willing to pay. Even if its positive sign indicates that the households' maximum WTP amount is upwardly biased, the coefficient.

Table 7: Aggregate WTP and possible revenue from improved watershed

\begin{tabular}{|c|c|c|c|c|c|c|c|c|c|}
\hline \multirow[t]{2}{*}{$\begin{array}{l}\text { WTP } \\
\text { classes } \\
(\text { In } \\
\text { ETB) }\end{array}$} & \multirow{2}{*}{$\begin{array}{l}\text { Mid } \\
\text { WTP } \\
\text { (In } \\
\text { ETB) } \\
65.18\end{array}$} & \multicolumn{2}{|c|}{$\begin{array}{l}\text { Respondents } \\
\text { willing to pay }\end{array}$} & \multicolumn{2}{|c|}{$\begin{array}{l}\text { Number of } \\
\text { households in } \\
\text { Mekelle city } \\
(131415)\end{array}$} & \multicolumn{2}{|c|}{$\begin{array}{l}\text { Possible } \\
\text { Total revenue from } \\
\text { sampled } \\
\text { respondents }\end{array}$} & \multicolumn{2}{|c|}{$\begin{array}{l}\text { Possible Total } \\
\text { revenue of all city } \\
\text { residents }\end{array}$} \\
\hline & & Number & $\%$ & Number & $\%$ & Revenue & $\%$ & Revenue & $\%$ \\
\hline 60 & 60 & 156 & 44.32 & 58243 & 44.32 & 9360 & 40.94 & 3494580 & 40.94 \\
\hline 120 & 120 & 32 & 9.09 & 11946 & 9.09 & 3840 & 16.8 & 1433520 & 16.8 \\
\hline 90 & 90 & 42 & 11.94 & 15690 & 11.94 & 3780 & 16.54 & 1412100 & 16.54 \\
\hline $65-85$ & 71.75 & 57 & 16.19 & 21276 & 16.19 & 4089.75 & 17.89 & 1526553 & 17.89 \\
\hline 30 & 30 & 50 & 14.2 & 18661 & 14.2 & 1500 & 6.56 & 559830 & 6.56 \\
\hline $10-25$ & 19.33 & 15 & 4.26 & 5599 & 4.26 & 289.95 & 1.27 & 108228.67 & 1.27 \\
\hline Total & & 352 & 100 & 131415 & 100 & 22859.7 & 100 & $\mathbf{8 , 5 3 4 , 8 1 2}$ & 100 \\
\hline
\end{tabular}

From the above table 7 the possible total revenue of all Mekelle city residents was 289,477.57 USD.

N.B. US Dollars to Ethiopian Birr exchange rate for September 30, 2019 was 1 USD- 29.4835 ETB.

Figure 3 below shows the aggregate demand curve for watershed ecosystem services improvements. Any point on the curve shows the households willing and prefer for the improved watershed ecosystem service. The data show total households of 58243, 11946, 15690, 21276, 18661 and 5599 could pay (in ETB) 60, 120, 90, $71.75,30$ and 19.33 respectively. But the households do not bid more than the corresponding value on the mid value WTP (in birr) in y-axis. The demand curve is negatively sloped indicating the fall of the demand for improved watershed ecosystem services as the second bid amount increase, like most other economic goods, other things remaining the same. If watershed is considered as a free resource or public good to the society, the consumers' surplus would be the total area under the demand curve. The area under the demand curve represents the gross value of consumers' surplus if the tariff rate is zero. Figure 5 shows the aggregate demand curve for the improved watershed ecosystem services using the observations in the study. Any point on the curve shows all the households that prefer the improved watershed service but do not bid more than the corresponding value on the mid WTP axis. 
Figure 3: The demand curve for the improved watershed

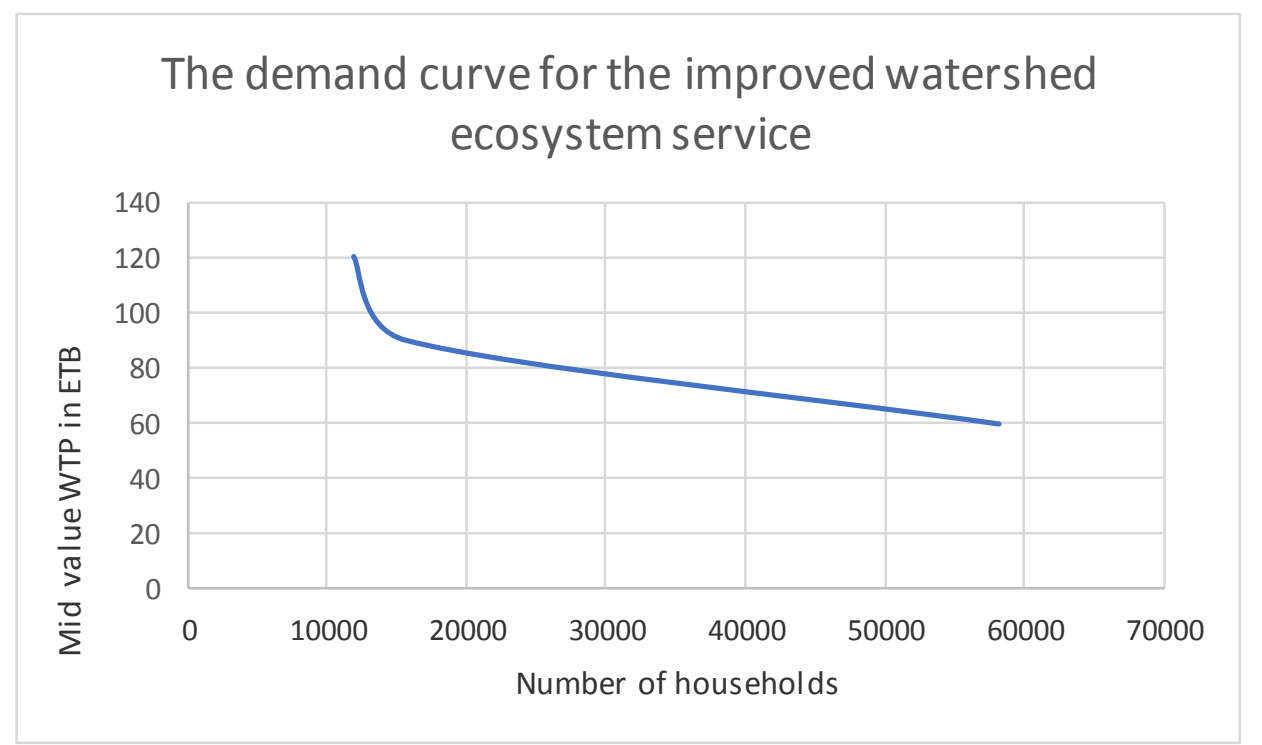

\subsection{Discussion}

The sustainability of ecosystem services from watershed in Mekelle city region depends on past and present conservation activities from all stakeholder living within the Mekelle city and its surrounding hinterlands. The contribution of funds from city residents can ensure the sustainability of bundles of ecosystem service. Mekelle city is enclaved by rural areas which are major sources of various ecosystem services. To understand whether ecological restoration activities in the watershed area feasible by Mekelle city resident, the study measured the current level of public support for proposed restoration activities in terms of hypothetical monetary payments added to a monthly water bill and other urban environmental services.

The elicitation method was the primary determinant of quality research findings in in the study. This study applied the NOAA (US National Oceanic and Atmospheric Administration)guidelines for contingent valuation including: personal interview, using WTP rather than WTA, using double bounded dichotomous choice format, adequately pre-test the survey, carefully pretesting historical LULC maps of the watersheds and LULC changes, using an accurate scenario description ,minimizing overestimation of WTP using conservative design, checking temporal consistencies of results, avoiding convenience samples and using representative samples, reminding respondents about budget constraints of Mekelle city administration, provide no answer or no opinion to respondents, checking respondents understanding and follow-up questions to valuation questions.

In addition to this, for households' preferences and willingness to pay for watershed services and concerning awareness a psychometric scale variables section was presented on a 5-point Likert scale was to measure the respondents' perception and attitude toward watershed conservation and their preferences. This is followed by respondents' socioeconomic profile. Following the recommendation by NOAA panel face-to-face survey mode was used for data collection. This technique is the commonest adopted as evident in the literature review. Besides, this method had the potential to attract the highest response. This survey result showed majority surveyed respondents are dissatisfied with the current watershed services and are willing to support the proposed scenario. The factors Influencing households' willingness to participate were identified from the survey result. In the CVM survey, four starting bid amounts were given for closed-ended dichotomous choice format together with openended question to ask respondents their maximum willingness to pay for improved watershed ecosystem services. The results showed respondents are influenced by initial bid amount.

This WTP results indicate that it is not related with education. This result, tough not conclusive, other researchers suggests that more educated households are more aware about the value of improved water services(Xiong, Kong, Zhang, Lei, \& Sun, 2018). Membership in environmental group has negative sign of coefficient. But previous studies show people who are members in environmental organization who voluntarily contribute to the society through monetary donations and/or active participation and mobilization to improve the environment. Individual's pro-environment attitudes and behavioral intentions enhance WTP.

The contingent valuation method has been widely used technique; this is probably due to its ability to estimate all types of values in particular non-use value of environmental goods and services. A study by (Cerda \& VáSQUEZ, 2005)suggest that there is not a significant difference between parametric and non-parametric welfare measures. A study by (Wendimu \& Bekele, 2011) on the determinants of individual willingness to pay for quality water supply in Wonji Shoa Sugar Estate, Ethiopia revealed that the income of the household, education level of 
the respondent, reliability on existing water supply, respondent perception about quality of the existing water supply, household family size and age of the respondent are significant variables that explain WTP. Another study by (Carandang, Calderon, Camacho, \& Dizon, 2009) in Metro Manila of Angat, Ipo, Umiray and La Mesa watersheds for Improved Management of Watershed identified the factors that significantly affect households willingness to pay were bid amount, occupation, additional water expenses, water distributor serving the household and income. But this study showed the major determinant factors that affect WTP from the region perspectives there are several explanatory variables that need attentions by decision makers.

Respondents current satisfaction with the existing watershed ecosystem service has negative sign of coefficient. But in other studies, a positive relationship existed between willingness to pay and this variable as households that are not satisfied with the existing ecosystem services are expected to have more willingness to pay for improved watersheds services The Tobit regression model result confirms the economic theory which says that income and quantity demanded for a particular commodity are positively related for the case of normal goods. The class boundaries for the MWTP amount expressed by sampled households during the survey were used to make the aggregation of total WTP, total revenue and deriving the demand curve for the watershed ecosystem services improvement.

The surveyed household paid an average income of birr 75 for their monthly consumption of water. The minimum and maximum monthly payment for water utility are 30 and 330 ETB. The World Bank's recommendations states that household should not spend more than $5 \%$ of their monthly income on water and sanitation. Therefore, this result suggests that the sampled households can spend more for improved watershed ecosystem services. Based on this the city residents monthly they can pay 130 ETB per month.

There is a rich literature that describes WTP participation decisions in environmental programs. However, few studies exist to solve the problem identified in this study. Different studies have taken into account different econometric techniques which are used commonly to measure willingness to pay of respondents for various goods. Several studies focused on single consumer good i.e water.However,this study focused on bundles of ecosystem services provided by watershed. Previous studies applied regression, Probit, OLS, logit models to analyze statistical relations between WTP and several independent variables. This study employed CVM. All of the mentioned methods have their own positives and negatives sides. The censored regression models are preferred for estimating the willingness to pay. The reason to use the Tobit models is that they are designed in such a way that they capture the full effect of the explanatory variables. This study applied double bounded dichotomous choice contingent valuation. However, few studies employed this approach. By asking respondent a doublebounded dichotomous choice question which second question depends on the response to the first initial bid question and to encourage respondents to state their true value, WTP of watershed ecosystem services improvement have been examined. Unlike previous studies using contingent valuation approach, this research is exceptional in its objectives and its implications for sustainable watershed management.

\section{Conclusion and recommendation}

Willingness to pay is a promising policy instruments for integrating economic payment to ensure sustainable watershed ecosystem services provision. This study analyzed both the source of ecosystem services and the demand side. The WTP survey was conducted based on face-to-face interview with 384 sampled households. The double-bounded dichotomous choice with an open-ended follow up elicitation format was used. The survey was analyzed using descriptive and econometric models. The econometric model estimation proves the WTP would be a useful approach to developing sustainable watershed management program.

The descriptive analysis showed majority of surveyed households had positive willingness to pay for improved watershed services. This shows that if the city's administration could implement the proposed scheme, in addition to solving the severe water problem and other ecosystem services of Mekelle city, it can collect more revenue. The explanatory variables were significant factors that affect positively and negatively households' probability of saying 'Yes' to initial bid offered to them. The results are promising conservation approach, it can benefit both users and upstream communities. The WTP survey of the study indicate the government can use these findings to guide the successful implementation of the proposed watershed improvement programs. In this regard, it is recommended that:(1) Design intervention strategies in order to sustain the provision of watershed ecosystem services through payment for ecosystem services schemes(2)Facilitate more voluntary donation in utility bills (3) Establishment of institutional framework and markets for ecosystem services (4) Environmental education and community based environmental management and(5)support community and civil society involvement in integrated watershed to build ownership and long-term support.

\section{Declaration of interest}

The authors declare that they have no competing interests. 
Ethics approval

Not applicable.

\section{Consent to participate}

The author needs to accept and confirm the manuscript have read and agreed to its content and are accountable for all aspects of the accuracy and integrity of the manuscript. The article is original, has not already been published in a journal, and is not currently under consideration by another journal.

\section{Consent for publication}

The author is volunteer for publication of original research findings entitled ' Willingness to pay for watersheds ecosystem services improvement in Mekelle city region: A Policy Implications for payment for ecosystem service". The author grants Journal of Economics and Sustainable Development a license to publish the article and identify itself as the original publisher.

\section{Availability of data and material}

The dataset(s) supporting the conclusions of this article is (are) available in the Google scholar, JSTOR, Google that all publicly available datasets are fully referenced in the reference list.

\section{Authors' contributions}

1) The Author (shishay kiros) makes substantial contributions to conception and design, and/or acquisition of data, and/or analysis and interpretation of data;

2) The Co-author (kumelachew yeshitela) contribution is on conceptual design, Interpretation of data and write up;

\section{Authors' information}

1.Kumelachew Yeshitela (Ph.D.) is an associate professor of Urban Ecology at Ethiopian Institute of Architecture, Building Construction and City Development, Addis Ababa University, Addis Ababa, Ethiopia. He is Chair of Ecosystem Planning and Management. He has published 44 scientific works in international reputable journals. Email: kumeyesh@gmail.com 2.Shishay is a Ph.D. Candidate in Environmental sustainability and Climate change resilience at Ethiopian Civil Service University, Addis Ababa.

Email: shishaykiros@gmail.com

\section{Acknowledgments}

My thanks go to Tigray Bureau of trade, industry and urban development, Tigray (Ethiopia), bureau of civil service and Ethiopian civil service university for giving me the opportunity to pursue this study and for the financial support, without which this achievement would not have been possible. I would like to thank all institutions and individuals at national, regional, district and city levels who provided me information for this study.

\section{References}

Abreha, A. G. (2014). Hydrogeochemical and Water Quality Investigation on Irrigation and Drinking Water Supplies in the Mekelle Region, Northern Ethiopia(MSC), University of Twente 2014.

Aredehey, G., Mezgebu, A., \& Girma, A. (2018). Land-use land-cover classification analysis of Giba catchment using hyper temporal MODIS NDVI satellite images. International journal of remote sensing, 39(3), 810-821.

Carandang, M. G., Calderon, M. M., Camacho, L. D., \& Dizon, J. T. (2009). Parametric and Non-parametric Models To Estimate Householdsâ€ $€^{\mathbf{T M}}$ Willingness To Pay For Improved Management of Watershed. Journal of Environmental Science and Management, 11(2).

Cerda, A., \& VáSQUEZ, F. (2005). Differences between parametric and non-parametric estimation of welfare measures: An application to the Rio Claro, Talca, Chile. Panorama socioeconómico(31), 22-31.

Danyang Feng, W. W., Long Liang, Li Li \& Guishen Zhao. (2018). Payments for watershed ecosystem services: mechanism, progress and challenges

Ecosystem Health and Sustainability, 4.

Freeman, A. M. (1993). The measurement of environmental and resource values resources for the future. Washington, DC, 516.

Girmay, E., Ayenew, T., Kebede, S., Alene, M., Wohnlich, S., \& Wisotzky, F. (2015). Conceptual groundwater flow model of the Mekelle Paleozoic-Mesozoic sedimentary outlier and surroundings (northern Ethiopia) using environmental isotopes and dissolved ions. Hydrogeology Journal, 23(4), 649-672.

Hanemann, M., Loomis, J., \& Kanninen, B. (1991). Statistical efficiency of double-bounded dichotomous choice contingent valuation. American journal of agricultural economics, 73(4), 1255-1263. 
Krejcie, R. V., \& Morgan, D. W. (1970). Determining sample size for research activities. Educational and psychological measurement, 30(3), 607-610.

Margaret Mejorada Calderon, K. P. A. A., Leo Kris Mariano Palao \& Rodel Diaz Lasco. (2012). Households' Willingness to Pay for Improved Watershed Services of the Layawan Watershed in Oroquieta City, Philippines. Journal of Sustainable Development, 6.

Max Nielsen-Pincus, P. S., Drew E. Bennett, Hannah Gosnell \& Robert Parker. (2017). The Influence of Place on the Willingness to Pay for Ecosystem Services. SOCIETY \& NATURAL RESOURCES, 30.

Perman, R., Ma, Y., McGilvray, J., \& Common, M. (2003). Natural resource and environmental economics: Pearson Education.

TCSA. (2019). Tigray population data Demography. Tigray stastical agency.

Tietenberg, T. (2003). Environmental and Natural Resource Economics, 6e Addison Wesley: Boston.

Veen, T. G. a. A. v. d. (2014). The Effect of Enclosures in Rehabilitating Degraded Vegetation: A Case of Enderta District, Northern Ethiopia

Forest Research.

Wendimu, S., \& Bekele, W. (2011). Determinants of individual willingness to pay for quality water supply: The case of Wonji Shoa Sugar Estate, Ethiopia. Journal of Ecology and the Natural Environment, 3(15), 474-480.

Xiong, K., Kong, F., Zhang, N., Lei, N., \& Sun, C. (2018). Analysis of the factors influencing willingness to pay and payout level for ecological environment improvement of the Ganjiang River basin. Sustainability, 10(7), 2149. 